\title{
Grafts of Brain-Derived Neurotrophic Factor and Neurotrophin 3-Transduced Primate Schwann Cells Lead to Functional Recovery of the Demyelinated Mouse Spinal Cord
}

\author{
Christelle Girard, ${ }^{1}$ Alexis-Pierre Bemelmans, ${ }^{2}$ Noëlle Dufour, ${ }^{2}$ Jacques Mallet, ${ }^{2}$ Corinne Bachelin, ${ }^{1}$ \\ Brahim Nait-Oumesmar, ${ }^{1}$ Anne Baron-Van Evercooren, ${ }^{1}$ and François Lachapelle ${ }^{1}$ \\ ${ }^{1}$ Institut National de la Santé et de la Recherche Médicale Unité 546, Laboratoire des Affections de la Myéline et des Canaux Ioniques Musculaires, and \\ ${ }^{2}$ Centre National de la Recherche Scientifique Unité 7091, Institut Fédératif de Recherche 70, Centre Hospitalier Universitaire Pitié-Salpêtrière, 75634 Paris \\ Cedex 13, France
}

\begin{abstract}
Experimental studies provided overwhelming proof that transplants of myelin-forming cells achieve efficient remyelination in the CNS. Among cellular candidates, Schwann cells can be used for autologous transplantation to ensure robust remyelination of lesions and to deliver therapeutic factors in the CNS. In the present study, macaque Schwann cells expressing green fluorescent protein (GFP) were infected with human immunodeficiency virus-derived vectors overexpressing brain-derived neurotrophic factor (BDNF) or Neurotrophin 3 (NT-3), two neurotrophins that also modulate glial cell biology. The ability of transgenic Schwann cells to secrete growth factors was assessed by ELISA and showed 35- and 62-fold increases in BDNF and NT-3, respectively, in transduced macaque Schwann cell supernatants. Conditioned media of BDNF- and NT-3-transduced Schwann cells reduced Schwann cell proliferation and favored their differentiation in vitro. Transgenic cells were grafted in demyelinated spinal cords of adult nude mice. Two behavioral assays showed that NT-3- and BDNF-transduced Schwann cells promoted faster and stronger functional recovery than GFP-transduced Schwann cells. Morphological analysis indicated that functional recovery correlated with enhanced proliferation and differentiation of resident oligodendrocyte progenitors and enhanced oligodendrocyte and Schwann cell differentiation. Moreover, NT-3-transduced Schwann cells provided neuroprotection and reduced astrogliosis. These results underline the potential therapeutic benefit of combining neuroprotection and activation of myelin-forming cells to restore altered functions in demyelinating diseases of the CNS.
\end{abstract}

Key words: primate; Schwann cell; neurotrophins; remyelination; neuroprotection; astrogliosis

\section{Introduction}

Experimental transplantation has provided overwhelming proof for the potential of repair of transplanted myelin-forming cells in the CNS. Schwann cells (SCs) are good candidates for such therapy (Baron-Van Evercooren and Blakemore, 2004). They are not a target in most dysmyelinating and demyelinating diseases of the CNS, can be easily expanded from adult human and nonhuman primate peripheral biopsies (Morrissey et al., 1995; AvellanaAdalid et al., 1998), and therefore are considered for autologous engraftment. Their transplantation in various animal models of

\footnotetext{
Received Dec. 1, 2004; revised June 13, 2005; accepted June 14, 2005.

This work was supported by the Institut National de la Santé et de la Recherche Médicale, The Myelin Project, and the Association Franco-Israélienne pour la Recherche Scientifique et Technologique (AFIRST). During this study, C.G. was a fellow of AFIRST and the Fondation Vaincre les Maladies Lysosomiales.

Correspondence should be addressed to either of the following: Anne Baron-Van Evercooren, Institut National de la Santé et de la Recherche Médicale Unité 546, Centre Hospitalier Universitaire Pitié-Salpêtrière, 105 Boulevard de I'Hôpital, 75634 Paris Cedex 13, France, E-mail: baron@ccr.jussieu.fr; or François Lachapelle, Institut National de la Santé et de la Recherche Médicale Unité 546, Centre Hospitalier Universitaire Pitié-Salpêtrière, 105 Boulevard de I'Hôpital, 75634 Paris Cedex 13, France, E-mail: lachapel@ccr.jussieu.fr.

A.-P. Bemelmans' present address: Oculogenetics Unit, Jules Gonin Eye Hospital, Lausanne, Switzerland.

N. Dufour's present address: Isotopic Imaging, Biochemical and Pharmacological Unit and Imagene Program, Service Hospitalier Frédéric Joliot, 91401 Orsay, France.

D01:10.1523/JNEUROSCI.4890-04.2005

Copyright $\odot 2005$ Society for Neuroscience $\quad$ 0270-6474/05/257924-10\$15.00/0
}

demyelination showed their participation in remyelination of CNS lesions (Blakemore et al., 1977; Duncan et al., 1981; Blakemore and Crang, 1985; Baron-Van Evercooren et al., 1992) and their ability to restore axonal conduction (Honmou et al., 1996). Moreover transplantation of SCs in the injured spinal cord promotes axonal regeneration (Xu et al., 1999; Oudega et al., 2001; Pearse et al., 2004). However, the number of remyelinated or regenerated axons often remains insufficient. Modifying SCs to express factors enhancing regeneration and remyelination could be one strategy to improve their capacity to repair the injured or demyelinated CNS. However, so far, these strategies developed in rodents focused on axonal protection and regeneration after trauma or nerve transections (Menei et al., 1998; Tuszynski et al., 1998). Few, if any, integrated strategies combining remyelination by grafted cells, activation of endogenous remyelination, and protection of axonal targets were proposed to repair the demyelinated CNS.

Neurotrophic factors such as brain-derived neurotrophic factor (BDNF) and Neurotrophin-3 (NT-3) promote neural protection, plasticity, and regeneration after spinal cord injury in the developing and adult CNS. BDNF and NT-3 modulate myelination in both the CNS and PNS, and NT-3 promotes oligodendrocyte precursor (OPC) proliferation, survival, and differentiation 
(Barres et al., 1993, 1994; McTigue et al., 1998; Yan and Wood, 2000). BDNF and NT-3 are also key modulators of SC biology. Although BDNF promotes myelin formation (Zhang et al., 2000; Tolwani et al., 2004), NT-3 is considered as a negative regulator of the SC myelination process (Chan et al., 2001). However, NT-3 is a prosurvival and promigratory factor for SCs in vitro (Meier et al., 1999; Yamauchi et al., 2004). Thus, BDNF or NT-3 administration could be of high interest to stimulate myelin repair.

We derived SCs from adult macaque biopsies and transduced them with human immunodeficiency virus-1 (HIV-1)-derived lentiviral vectors expressing BDNF or NT-3. We demonstrate that overexpression of BDNF or NT-3 by the transduced SCs improves their therapeutic effects after their transplantation into demyelinated nude mice spinal cords.

\section{Materials and Methods \\ Animals}

Macaca fascicularis monkeys (5- to 8-year-old males and females) were raised in the Institut National de la Recherche Agronomique/Institut National de la Santé et de la Recherche Médicale animal facility (Jouyen-Josas, France). OF1-Nude mice (6 weeks of age) were purchased from Charles River Laboratories (l'Abresle, France). All experiments were performed according to European Community regulations and ethical policies (authorization A602626 26/03/1990; reviewed March, 2000) as well as the Policies on the Use of Animals and Humans in Neuroscience Research approved by the Society for Neuroscience in January, 1995.

\section{Macaque Schwann cell purification and expansion}

Solutions for culture were obtained from Invitrogen (Cergy-Pontoise, France). All other products were purchased from Sigma (Saint-QuentinFallavier, France) if not specified otherwise. SCs were derived from sural nerve biopsies $(2 \mathrm{~cm})$ of adult Macaca fascicularis and purified after repetitive explantation of nerve fragments in vitro (Avellana-Adalid et al., 1998). Biopsies were performed under ketamine $(10 \mathrm{mg} / \mathrm{kg}) /$ xylazine $(0.5 \mathrm{mg} / \mathrm{kg})$ anesthesia. Pain avoidance was obtained by local administration of lidocaine. Highly purified SC populations containing $95-98 \%$ of S100-expressing SCs were expanded in proliferating medium composed of DMEM containing $10 \%$ heat-inactivated fetal bovine serum (FBS) and supplemented with antibiotics (penicillin, $100 \mu \mathrm{g} / \mathrm{ml}$; streptomycin, $100 \mathrm{U} / \mathrm{ml}$; Biomedia, Boussens, France), human recombinant Neu differentiation factor (NDF) $(10 \mathrm{ng} / \mathrm{ml}$; Amgen, Thousand Oaks, $\mathrm{CA})$, insulin $(10 \mu \mathrm{g} / \mathrm{ml})$, and forskolin $(1 \mu \mathrm{g} / \mathrm{ml})$. SCs were grown in this medium 1-2 weeks before transplantation.

\section{Lentivirus production and SC infection}

Lentiviral vector shuttle plasmids were generated from pTRIP [phosphotyrosine receptor kinase (Trk) interacting protein] green fluorescent protein (GFP) plasmid (Zennou et al., 2000). BDNF and NT-3 cDNAs were cloned by PCR from a human cDNA library (Promega, Madison, WI). The woodchuck hepatitis virus posttranscriptional regulatory element (WPRE) was added downstream of the cDNAs to enhance transgene expression (Zennou et al., 2001). Lentiviral particles were obtained by transient transfection of $293 \mathrm{~T}$ cells with the vector shuttle plasmid, encapsidation, and envelope plasmid as described previously (Charneau et al., 1992). Vector stocks were then purified from the cell supernatant and concentrated by ultracentrifugation. Total particle concentration of viral stocks was quantified by p24 antigen ELISA assay (Beckman Coulter, Fullerton, CA). Titers reached $88 \mathrm{ng} / \mu \mathrm{l}$ for HIV-NT-3 vector, $181 \mathrm{ng} / \mu \mathrm{l}$ for HIV-BDNF vector, and $228 \mathrm{ng} / \mu \mathrm{l}$ for HIV-GFP vector.

For transduction, primary macaque SCs were plated at a density of $1.10^{5}$ cells per well in six-well dishes (ATGC, Marne la Vallée, France) substrated with collagen $(2 \mathrm{mg} / \mathrm{ml})$. HIV-NT-3 and HIV-BDNF suspensions were added to the dishes at a 24 concentration of $100 \mathrm{ng} / \mathrm{ml}$ in $2 \mathrm{ml}$ of proliferation medium. After $72 \mathrm{~h}$ of incubation at $37^{\circ} \mathrm{C}$, cells were washed with PBS and fed with proliferation medium. Transduced and control SCs were infected with HIV-GFP vector $8 \mathrm{~d}$ before transplantation to allow their easy visualization in the host tissue (p24 concentration of $100 \mathrm{ng} / \mu \mathrm{l}$ for $2 \mathrm{ml}$ ). Under these conditions, $90 \%$ of the SC population was $\mathrm{GFP}^{+}, 48 \mathrm{~h}$ after infection. A decrease in the level and percentage of transgene expression after successive freezing and thawing of the different transduced SC populations were never observed.

\section{$B D N F$ and NT-3 production assay}

BDNF and NT-3 production assays were performed using BDNF and NT-3 Emax R Immunoassay Systems (Promega), sensitive to $15.6 \mathrm{pg} / \mathrm{ml}$ and $10 \mathrm{pg} / \mathrm{ml}$, respectively, for commercial BDNF and NT-3 (Promega). Immobilon plates coated with anti-human BDNF monoclonal antibody or anti-human NT-3 polyclonal antibody, respectively, were incubated with several dilutions of media or spinal cord extracts. For ELISA assays on the spinal cord, BDNF and NT-3 proteins were extracted using a lyse buffer containing $1 \%$ Tween 20 and an anti-protease mixture in PBS. Spinal cord extracts were centrifuged for $15 \mathrm{~min}$ at $13,000 \times \mathrm{g}$ and at $4^{\circ} \mathrm{C}$. The BDNF ELISA was developed using a polyclonal anti-BDNF antiserum revealed by a species-specific anti-IgY antibody conjugated to horseradish peroxidase for detection. The NT-3 ELISA was developed using a monoclonal anti-NT-3 antibody, and a tertiary antibody conjugated to horseradish peroxidase (anti-mouse IgG) was added for detection. The substrate was incubated for $2-5 \mathrm{~min}$ or until adequate signal was detected. ELISA reactions were stopped by the addition of $1 \mathrm{~m}$ phosphoric acid. Optical densities were measured at a wavelength of 620 and $450 \mathrm{~nm}$.

\section{Proliferation assay}

To assay the effect of BDNF and NT-3 on proliferation, SCs were plated on four-well Greiner Petri dishes (ATGC) substrated with collagen (2 $\mathrm{mg} / \mathrm{ml}$ ) at a density of $10.10^{3}$ cells/well. Transduced SCs were maintained in DMEM-FBS with insulin $(10 \mu \mathrm{g} / \mathrm{ml})$ and forskolin $(1 \mu \mathrm{g} / \mathrm{ml})$ but without NDF $\beta$ to avoid synergy with BDNF or NT-3. Native SCs were maintained in the same medium either conditioned by transduced SCs or supplemented with commercial neurotrophins (Chemicon, Temecula, CA). Cells were labeled with bromodeoxyuridine (BrdU; $15 \mathrm{~mm}$ every $24 \mathrm{~h}$ ) and fixed 24,48 , and $72 \mathrm{~h}$ after plating with $4 \%$ paraformaldehyde. For BrdU detection, cells were treated for $30 \mathrm{~min}$ at $37^{\circ} \mathrm{C}$ with $2 \mathrm{~N}$ $\mathrm{HCl}$ in PBS containing $0.3 \%$ Triton $\mathrm{X}-100$ and rinsed twice in $0.1 \mathrm{M}$ sodium tetraborate buffer, $\mathrm{pH} 8.5$, for $10 \mathrm{~min}$ at $37^{\circ} \mathrm{C}$. After several washes in $0.1 \mathrm{M}$ PBS, cells were incubated with rat anti-BrdU antibody ( $1: 100$; Harlan, Loughborough, UK), washed carefully, and incubated for $1 \mathrm{~h}$ at $37^{\circ} \mathrm{C}$ with the appropriate fluorochrome-labeled secondary antibody.

\section{Differentiation assay}

To assay differentiation of transduced SCs, cells were grown on four-well Petri dishes substrated with collagen in DMEM-N2 composed of DMEM (50\%), HAM F-12 (50\%), insulin $(10 \mu \mathrm{g} / \mathrm{ml})$, bovine serum albumin $(300 \mu \mathrm{g} / \mathrm{ml})$, and N2 additives (Bottenstein and Sato, 1979) to withdraw SCs from the cell cycle and prime them for differentiation (Bachelin et al., 2005). Native SCs were incubated with the same medium either conditioned by transduced SCs or supplemented with commercial neurotrophins. Cells were double stained for GFP (1:100; Interchim, Montluçon, France) and S100 (1:100; Dako, High Wycombe, UK and Glostrup, Denmark) as a general marker of SCs or galactosyl cerebroside (GalC) [1:70; mouse IgG3 hybridoma (Ranscht et al., 1982)] for promyelinating SCs.

\section{Demyelination and SC transplantation}

Mice were anesthetized with ketamine ( $100 \mathrm{mg} / \mathrm{kg}$, i.p.) and xylazine (10 $\mathrm{mg} / \mathrm{kg}$, i.p.). Demyelination was obtained by stereotaxic injection $(0.1$ $\mu \mathrm{l} / \mathrm{min}$ ) of $1 \mu \mathrm{l}$ of $1 \%$ lysophosphatidylcholine (LPC) in the spinal cord at the T1/T2 level of the dorsal funiculus. The demyelination site was marked with charcoal. Forty eight hours after demyelination, SCs ( $1 \mu \mathrm{l}$ of a $5 \times 10^{4}$ cells/ $\mu$ l suspension) transduced with the lentiviral vectors encoding GFP, BDNF, or NT-3 were grafted in the demyelinated area (Baron-Van Evercooren et al., 1992). Five groups of five series were performed as follows: unlesioned mice, demyelinated mice without graft, demyelinated mice engrafted with GFP-SCs, GFP/BDNF-SCs, or GFP/ NT-3-SCs. The first group was dedicated to PCR analysis $(n=10$ in each series), the second to ELISA assays ( $n=10$ in each series), the third and fourth to behavioral assays and morphological analysis $(n=10$ in each series), and the fifth to morphological analysis ( $n=30$ in each series). To 
label dividing cells, mice of the last series received a double intraperitoneal injection of $\mathrm{BrdU}(0.1 \mathrm{mg} / \mathrm{g}) 4$ and $2 \mathrm{~h}$ before they were killed.

\section{Reverse transcription-PCR analysis}

Twenty-one days postinjection (p.i.), mice were killed by lethal doses of pentobarbital. Spinal cord fragments containing the lesions were dissected $(0.5 \mathrm{~cm}$ on each side of the charcoal mark), immediately frozen in dry ice, and stored at $-80^{\circ} \mathrm{C}$ until use. Total RNA was isolated with TRIZOL (Invitrogen, Cergy-Pontoise, France) reagent according to the instructions of the manufacturer, quantified, and analyzed by Agilent Bioanalyser 2100 (Agilent, Massy, France). Expression of recombinant human BDNF (rhBDNF) and rhNT-3 mRNA in the grafted spinal cords was assessed by reverse transcription (RT)-PCR. RNA were treated with RNase-free DNase-I to digest any contaminating genomic DNA and were reverse-transcribed using oligodT according to the instructions of the manufacturer (Invitrogen). The resulting cDNA was quantified and amplified (30 cycles) by standard PCR using the following parameters: $30 \mathrm{~s}$ at $94^{\circ} \mathrm{C}, 1 \mathrm{~min}$ at $55^{\circ} \mathrm{C}$, and $1 \min 45 \mathrm{~s}$ at $72^{\circ} \mathrm{C}$ for BDNF, NT-3, and GFP mRNA; and $1 \mathrm{~min}$ at $94^{\circ} \mathrm{C}, 1 \mathrm{~min}$ at $53^{\circ} \mathrm{C}$, and $2 \mathrm{~min}$ at $72^{\circ} \mathrm{C}$ for proteolipid protein (PLP)/DM20 and actin mRNA. rhNT-3 was amplified using NT-3 sense and WPRE antisense primers and rhBDNF using PGK2 (phosphoglycerate kinase 2) sense and BDNF antisense primers. Primer sequences are available on request. Lentiviral shuttle plasmids were used as control. The ratio of DM20 and PLP mRNA, used as an index of maturation of the oligodendroglial population (Mathisen et al., 2001), was quantified in our study by semiquantitative RT-PCR on control and grafted spinal cord extracts. PCR products were analyzed and quantified by capillary electrophoresis on a DNA-1000 (Agilent). Results of semiquantitative RT-PCR were expressed as a percentage of the average concentration in the control tissue after normalization by the $\beta$-actin mRNA expression level.

\section{Behavioral assays}

Rotarod assay. Global locomotor performances were tested using a rotarod (Letica, Barcelona, Spain), which measures coordination balance and motor control of the hindlimb (Dunham and Miya, 1957). This method has been used extensively to evaluate the effect of diffuse or focal demyelination and spontaneous or therapeutic remyelination in the CNS (McGavern et al., 1999; Murray et al., 2001; Cao et al., 2004). Animals were trained twice for $10 \mathrm{~min}$, for two consecutive days before the beginning of each experiment. Tests were performed every $3-4 \mathrm{~d}$ starting at $3 \mathrm{~d}$ and then to $25 \mathrm{~d}$. Mice were placed on the rod and tested at increasing rotation speeds (for a maximum of $5 \mathrm{~min}$ ), the lowest rate beginning at 4 $\mathrm{rpm}$. The time during which each animal was able to stay on the rod was quantified. Each mouse rested for $30 \mathrm{~min}$ between tests to reduce stress and fatigue.

Grid walk assay. Fine locomotor performances were assayed, adapting the grid walk task assay to assess deficit associated with damages of the corticospinal tract in an animal model of inflammatory demyelination (Kerschensteiner et al., 2004). The study was performed using the Locotronic device (Intellibio, Nancy, France), an automated version of the grid-walk task assay. The animals walk within a blind corridor on a 1-m-long runway of metal bars elevated $25 \mathrm{~cm}$ above the floor. Footfalls (errors), defined as drops of the foot below the grid, are detected by infra-rated sensors localized on both sides of the ladder. The number of steps, the precise duration, and location of all errors are recorded, and errors of forefeet and hindfeet and tail can be discriminated. In view of the thoracic location of the lesion, we counted the number of hindfeet footfalls, which mainly reflect deficits in the descending motor pathway (Kerschensteiner et al., 2004).

For each assay, 10 animals per series were tested. In all cases, tests were performed every $3 \mathrm{~d}$ from day 4 to day 25 p.i. The mean behavioral score and SEMs were calculated. Series were initially compared using ANOVA (two-way ANOVA). A Tukey's test was then used for multiple comparisons between series. Results of both tests were taken to be significant for $p<0.001$.

\section{Immunohistochemistry and histology}

Mice were killed at 7, 15,21, and $25 \mathrm{~d}$ p.i. with lethal doses of pentobarbital and were intracardially perfused with a $2 \%$ solution of paraformal- dehyde (Merck, Darmstadt, Germany) in PBS (0.1 m, pH 7.4). Spinal cords were dissected out, kept in the same fixative for $2 \mathrm{~h}$, and stored overnight at $4^{\circ} \mathrm{C}$ in a solution of $0.1 \mathrm{M} \mathrm{PBS}$ containing $20 \%$ sucrose. They were then frozen in isopentane $\left(-60^{\circ} \mathrm{C}\right)$ and stored at $-20^{\circ} \mathrm{C}$ until use. Sagittal sections ( $10 \mu \mathrm{m}$ thick) were obtained using a Reichert-Jung cryostat (Leica, Rueil-Malmaison, France) and collected on gelatin-coated slides. Grafted cells were identified by anti-human nuclei (1:50; Chemicon) or anti-GFP labeling. Anti-NG2 was used to detect OPCs (Nishiyama et al., 1996), anti-PLP (1:200) (Klinguer and Trifilieff, 1994) to detect CNS myelin, and anti-Pzero protein (P0) (1:75; mouse IgG hybridoma) (Yoshimura et al., 1996) to detect PNS myelin. To analyze the astrogliosis, sections were double stained for GFAP in combination with the following antisera: laminin $\gamma 1$ (1:100; Chemicon) for the laminin $\beta 2$ chain or anti-Cs56 (1:200; Sigma) for heparan sulfate proteoglycans. Anti-growth-associated protein-43 (anti-GAP-43) (1:100; Chemicon) was used to detect regenerating axons and anti-2F11 (1:200; Abcys, Paris, France) or Bodian stain to detect axons. Luxol fast blue and cresyl violet were used to visualize lesion profiles.

Sections were pretreated with ethanol $(5 \mathrm{~min})$ for P0 staining and Triton X-100 for GFP and NG2. They were incubated with primary antisera for $1 \mathrm{~h}$ at $37^{\circ} \mathrm{C}$ or overnight at $4^{\circ} \mathrm{C}$, rinsed, and incubated with the appropriate secondary antibodies for $1 \mathrm{~h}$ at $37^{\circ} \mathrm{C}$. Anti-BrdU combined with anti-NG2 (1:200; Chemicon) or anti-GFAP was used to identify dividing OPCs and astrocytes. Sections were counterstained with Hoechst, washed, and mounted with fluoromount.

\section{Quantification and statistical analysis}

Statistical analysis of the effect of growth factor treatment on SC proliferation and differentiation in vitro was assessed by Student's $t$ test. Three thousand cells were counted per medium condition (control, GFP, BDNF, and NT-3), and assays were run in triplicate.

In vivo results were obtained after analysis of six sections $100 \mu \mathrm{m}$ apart for each animal ( $n=10 /$ series). For cell proliferation (BrdU), sections were visualized with a fluorescent DBM Leica microscope, and quantification was performed with the Qwin software. Lesion areas were measured from adjacent luxol fast blue-stained serial section, and data were expressed per surface area. The effect of growth factor treatments on remyelination, SC survival, and neuroprotection was performed using an SP2 AOBS Leica confocal microscope. Quantification was performed according to a modification of the Mc Tigue method (McTigue et al., 1998). Sections were scanned at $20 \times$ to define the limits of the lesion and magnified at $80 \times$ to quantify myelin figures. Myelin figures were defined as PLP or P0 profiles surrounding 2F11 labeled axons. Measurements of the total cross-sectional area of the lesion and of the amount of immunopositive profiles for P0, GFP, PLP, and 2F11 staining in the lesion were made using the computerized-assisted image analysis ImageJ (Wayne Rasband, National Institutes of Health, Bethesda, MD). Data on P0, PLP, and GFP were expressed per lesion. The density of axons was evaluated drawing three parallel lines of $200 \mu \mathrm{m}$ in length and apart from $25 \mu \mathrm{m}$ on each section in the lesion. The number of axonal profiles crossing each line was estimated per surface area.

Statistical analysis was performed using the Student's $t$ test.

\section{Results}

\section{Secretion and biological effect of BDNF and NT-3 in vitro}

We used RT-PCR to measure mRNA levels of BDNF and NT-3 in transduced SCs $48 \mathrm{~h}$ after infection and showed the presence of rhBDNF and rhNT-3 transcripts in BDNF-SCs and NT-3-SCs, respectively (Fig. $1 A$ ). We next assayed the release of BDNF and NT-3 by ELISA on media conditioned for $48 \mathrm{~h}$ by transduced SCs and found 35- and 62.5-fold increases, respectively, in BDNF and NT-3 released by transduced SCs compared with native SCs with $0.25 \mathrm{ng} / \mathrm{ml}$ and $0.012 \mathrm{ng} / \mathrm{ml}$ per $10^{6}$ cells for nontransduced SCs and $8.75 \mathrm{ng} / \mathrm{ml}$ and $0.75 \mathrm{ng} / \mathrm{ml}$ per $10^{6}$ cells for BDNF and NT-3 transduced SCs, respectively (Fig. $1 B, C$ ). Similar results were found after double infection with HIV-GFP (data not shown).

The biological activity of the secreted neurotrophins was examined on transduced and native SCs and was compared with 

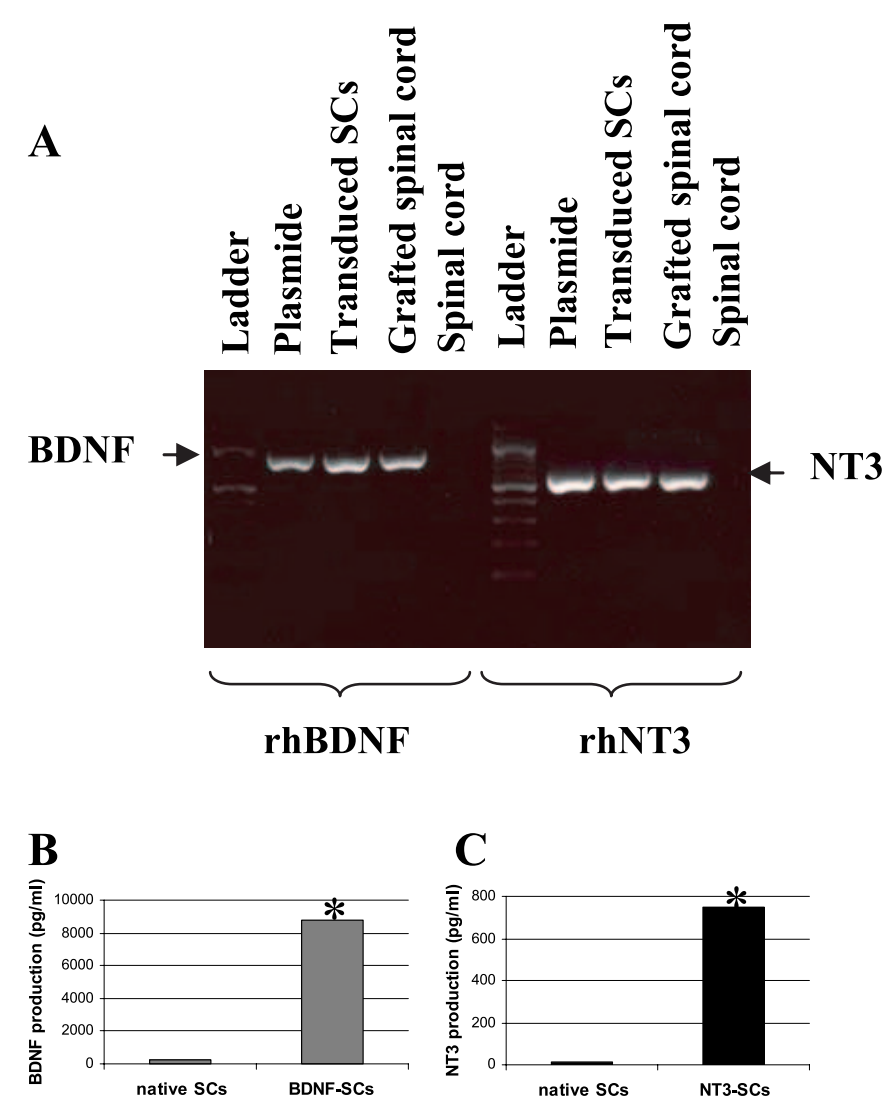

Figure 1. In vitro detection of rhBDNF and rhNT-3 transcripts $(\boldsymbol{A})$ and BDNF-transduced ( $\boldsymbol{B})$ and NT-3-transduced (C) SC release. ELISA revealed 35-fold and 62.5-fold increases in BDNF and NT-3, respectively, released by BDNF and NT-3-SCs compared with native SCs (Student's $t$ test; ${ }^{*} p<0.001$ compared with native $S(s)$.

commercial neurotrophins used at the same concentrations. Transduced SCs were plated for $72 \mathrm{~h}$ in DMEM-FBS without NDF $\beta$ to assay proliferation. The percentage of native, GFP-, BDNF-, and NT-3-transduced SCs incorporating BrdU was decreased of fourfold for BDNF-SCs $(12 \pm 1.3 \%)$ and 4.7 -fold for NT-3-SCs $(10.3 \pm 0.9 \%)$ compared with native SCs (47.9 \pm $1.3 \%$ ) (Fig. 2), thus indicating that BDNF and NT-3 inhibited transduced SC proliferation. Transduced SCs were plated for $72 \mathrm{~h}$ in DMEM-N2 to assay differentiation. After 72 h, $95.4 \pm 2.4 \%$ of BDNF-SCs and $91.6 \pm 1.7 \%$ of NT-3-SCs were $\mathrm{GalC}^{+}$(Fig. 2), demonstrating that both factors increased SC differentiation. This autocrine effect was mostly attributable to the growth factor overexpression, because lentiviral infection with HIV-GFP alone promoted only a slight level of SC differentiation (62.4 $\pm 1.5 \%$ of SCs expressing GalC), compared with nontransduced SCs (44.4 $\pm 2.7 \%)$. Similar results were found with BDNF- and NT-3-transduced SCconditioned medium as well as with commercial BDNF and NT-3 on native SCs (data not shown). This bioassay confirmed that BDNF and NT-3 secreted from BDNF- and NT-3-transduced SCs were biologically active and promoted SC differentiation.

\section{BDNF- and NT-3-transduced SCs promote} functional recovery

To investigate the effect of BDNF and NT-3 on functional recovery, GFP-, BDNF-, and NT-3-transduced SCs were grafted in LPC-induced myelin lesions of the nude mouse spinal cord. We tested the locomotor performances of each series from 3 to $25 \mathrm{~d}$ p.i. using the rotarod (Fig. $3 A$ ) or grid walk (Fig. $3 B$ ) behavioral tests. In all series, the average gradient of motor activity score was

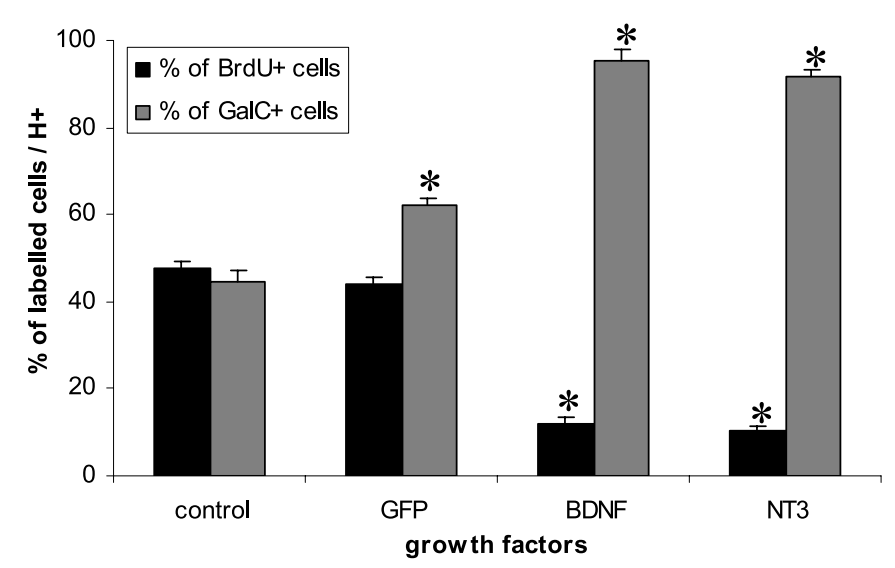

Figure 2. In vitro quantification of the number of $\mathrm{BrdU}^{+}$- and $\mathrm{GalC}^{+}$-labeled cells in control and transduced SCs. To assay proliferation, cells were grown for $72 \mathrm{~h}$ in DMEM-FBS. To assay differentiation, cells were grown for $72 \mathrm{~h}$ in DMEM-N2 without FBS and NDF $\beta$. The percentage of BrdU ${ }^{+}$cells was strongly reduced in BDNF-and NT-3-expressing SCs compared with controls and GFP-expressing cell populations. The percentage of GalC ${ }^{+}$cells was strongly increased in the BDNF and NT-3 and, to a lesser extent, in the GFP-expressing cells and controls (Student's $t$ test; ${ }^{*} p<0.001$ compared with control).
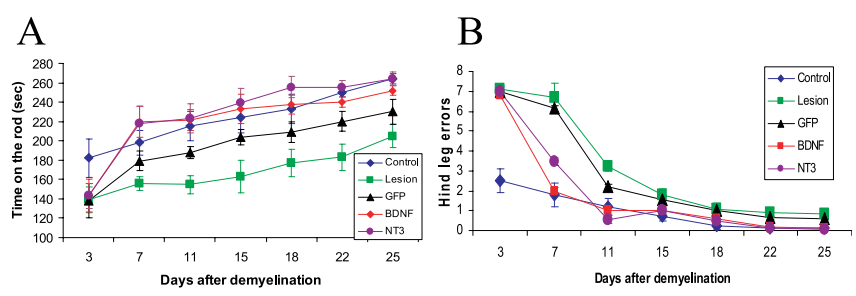

Figure 3. Effect of $\mathrm{SC}$ transplantation on motor performances. $\boldsymbol{A}$, Rotarod assay scores. $\boldsymbol{B}$, Grid walk assay scores. The groups transplanted with HIV-BDNFSCs or the HIV-NT-3 SCs showed a dramatic improvement of their motor score from $7 \mathrm{~d} \mathrm{p}$.i. From this stage, their score improved significantly over the demyelinated ungrafted and the unlesioned animals. ANOVA showed a group effect $(p<0.001)$, indicating overall differences between the various transplantation groups.

similar, demonstrating that the different conditions did not alter the learning performances of the animals. Lesioned mice showed a decrease in the motor scores reflecting most likely postoperative conditions $4 \mathrm{~d}$ p.i. GFP-grafted mice partially improved with scores significantly different from the unlesioned animals throughout the study and from the ungrafted demyelinated mice from $22 \mathrm{~d}$ p.i. BDNF- and NT-3-grafted animals dramatically improved rapid recovery from day 7 for rotarod and grid walk assays with values significantly different from the lesioned animals and GFP-grafted animals but not from the unlesioned animals. ANOVA analysis showed a group effect, with $p<0.001$, indicating overall differences between the different transplantation groups.

\section{Effect of BDNF and NT-3 on SC survival and differentiation in vivo}

We used RT-PCR to assess whether transduced SCs synthesize $\mathrm{BDNF}$ and NT-3 in vivo $21 \mathrm{~d}$ p.i. RT-PCR confirmed the presence of rhBDNF and rhNT-3 transcripts in the spinal cords grafted with BDNF- and NT-3-transduced SCs (Fig. 1A). To analyze the effect of BDNF and NT-3 overexpression on SC survival $21 \mathrm{~d}$ p.i., grafted SCs were visualized by GFP and anti-human nuclei labeling (Table 1). We found a good correlation between cells labeled with anti-human nuclei and GFP with 74,80 , and $88 \%$ of GFP ${ }^{+}$ SCs in mice grafted with GFP-, BDNF-, and NT-3-transduced SCs, respectively. Moreover, we found a twofold increase of 
Table 1. Effect of growth factor overexpression on SC survival, recruitment, and differentiation in vivo

\begin{tabular}{|c|c|c|c|c|c|}
\hline Series & Anti-human nuclei ${ }^{+}$cells & $\mathrm{GFP}^{+}$cells & $\mathrm{PO}^{+}$structures & $\mathrm{GFP}^{+} / \mathrm{PO}^{+}$structures & $\mathrm{GFP}^{-} / \mathrm{PO}^{+}$structures \\
\hline Lesion & 0 & 0 & $6 \pm 2.7$ & 0 & $6 \pm 2.7$ \\
\hline GFP & $254 \pm 32$ & $188 \pm 47$ & $48 \pm 11$ & $26 \pm 7$ & $22 \pm 5.8$ \\
\hline BDNF & $328 \pm 49$ & $264 \pm 72$ & $457 \pm 82$ & $31 \pm 6$ & $426 \pm 71$ \\
\hline NT-3 & $421 \pm 27$ & $368 \pm 82$ & $492 \pm 91$ & $127 \pm 45$ & $365 \pm 82$ \\
\hline
\end{tabular}

Data represent the number of $\mathrm{GFP}^{+}$cells and $\mathrm{PO}^{+}$and GFP $/ \mathrm{PO}^{+}$structures \pm SEM per lesion in the four experimental series $(n=20$ per series). Statistical differences were obtained between all groups for $p<0.001$.

$\mathrm{GFP}^{+}$/anti-human nuclei ${ }^{+}$SCs in NT-3SC-grafted mice compared with GFP-SCgrafted mice, suggesting that NT-3 favored the survival of the grafted SCs.

The relative contribution of the grafted SC population to remyelination was assayed by the combined detection of GFP and P0 myelin-like profiles (Fig. 4M-P; Table 1). The number of $\mathrm{GFP}^{+} / \mathrm{P}^{+}$ myelin-like profiles was not increased in BDNF-SC-grafted mice compared with GFP-SC-grafted mice but was 4.4-fold higher in NT-3-SC-grafted mice, demonstrating that NT-3, but not BDNF, favors the differentiation of the transplanted SCs in myelin-forming cells.

LPC lesions of the spinal cord are commonly invaded by endogenous SCs (Blakemore et al., 1977). Therefore, we examined the effect of the growth factor overexpression on SCs based on the immunodetection of $\mathrm{PO}^{+} / \mathrm{GFP}^{-}$structures (Table 1). Twenty-one days after infection, we found a small number of axons wrapped by $\mathrm{P}^{+} / \mathrm{GFP}^{-}$myelin-like profiles $\left(6 \pm 2.7 \mathrm{P}^{+} / \mathrm{GFP}^{-}\right)$in ungrafted lesions. However, the number of $\mathrm{P}^{+} /$ $\mathrm{GFP}^{-}$myelin-like profiles per lesion was increased 3.6-fold, 71-fold, and 61-fold in GFP-, BDNF-, and NT-3-SC-grafted lesions, respectively, suggesting that $\mathrm{BDNF}$ and NT-3 strongly promoted the recruitment and/or differentiation of host SCs in the lesion. Among these GFP ${ }^{-}$SCs, 26, 20, and $12 \%$ were primate SCs (anti-human nuclei-positive cells) in mice grafted with GFP-, BDNF-, and NT-3-SCs, respectively.

Finally, we quantified the effect of growth factor overexpression on global SC remyelination (endogenous and graft) based on the detection of all $\mathrm{P}^{+}$structures (Fig. $4 I-L, R)$. Although rare $\mathrm{P}^{+}$ profiles $(2 \pm 0.1)$ were observed in SCGFP-grafted lesions and none in ungrafted lesions by $15 \mathrm{~d}$, BDNF-SC- and NT-3-SCgrafted lesions contained $51 \pm 10$ and $47 \pm 9.7$, respectively. The quantity of $\mathrm{P}^{+}{ }^{+}$structures increased fourfold, ninefold, and 10-fold in GFP-SC-, BDNF-SC-, and NT-3-SC-grafted lesions $21 \mathrm{~d}$ p.i.

\section{BDNF and NT-3 increase proliferation of endogenous NG2 ${ }^{+}$ OPCs in vivo}

The effect of both factors on cell proliferation in the lesion was analyzed by immunodetection of BrdU at 7 and $15 \mathrm{~d}$ p.i. Quantification of the number of $\mathrm{BrdU}^{+}$cells in the lesion at $7 \mathrm{~d}$ p.i. showed that

Q
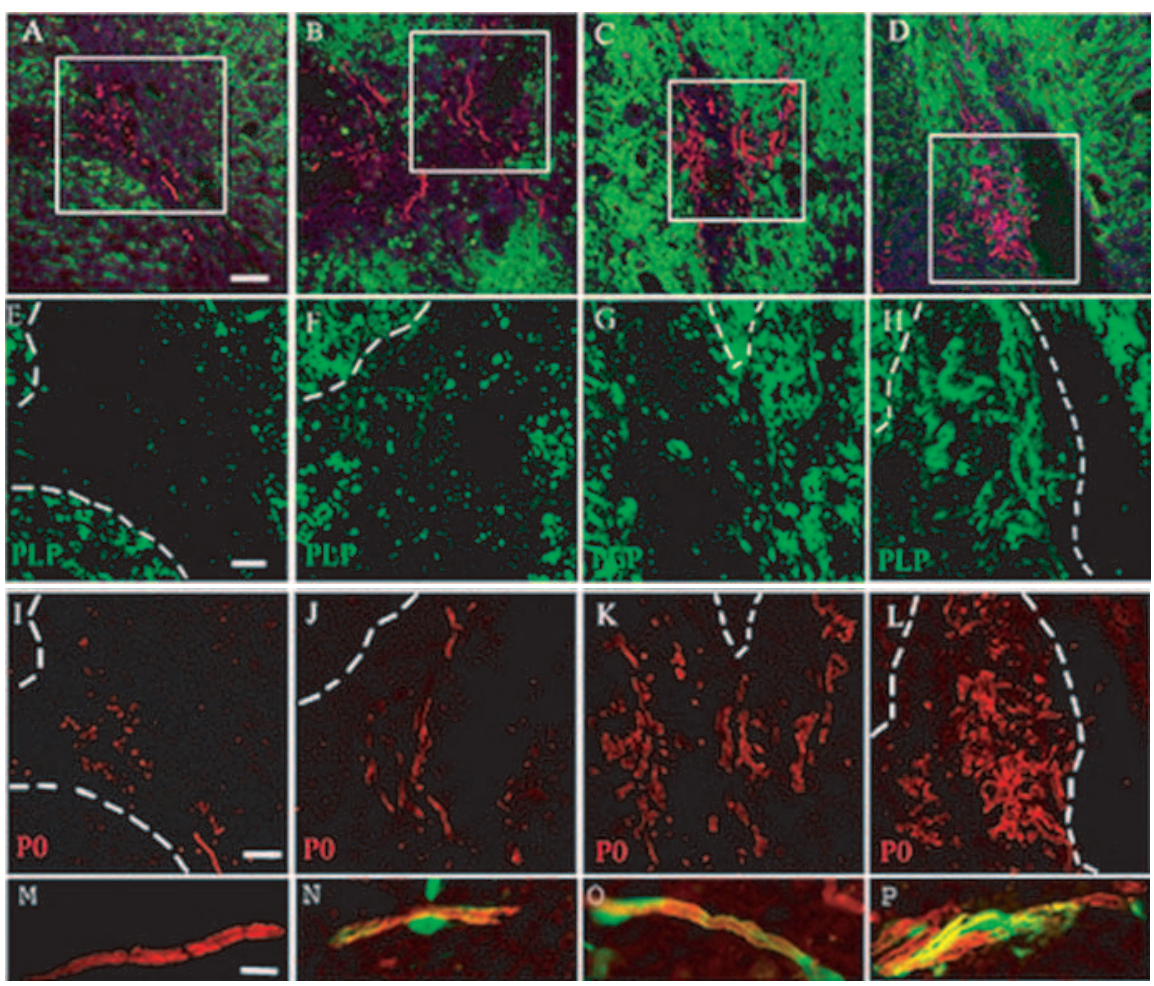

$\mathrm{R}$
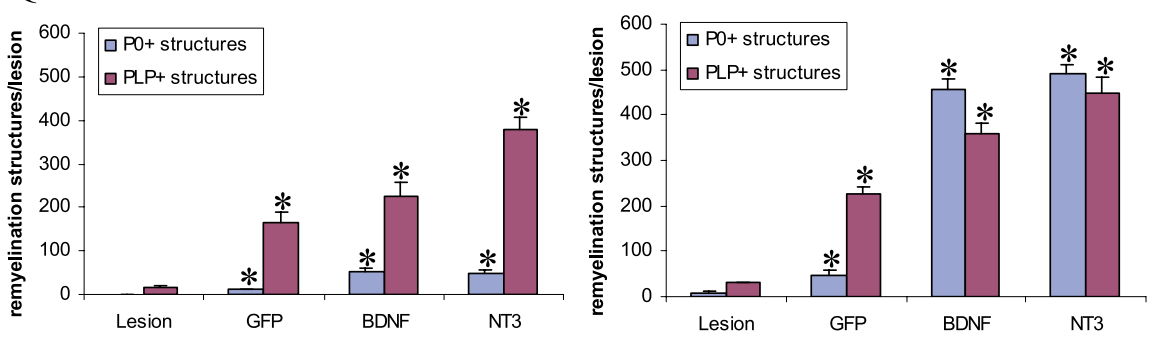

Figure 4. Effect of NT-3 and BDNF on CNS and PNS remyelination. $A-L$, Double immunolabeling of P0 and PLP in ungrafted lesions $(\boldsymbol{A}, \boldsymbol{E}, \boldsymbol{I})$ and GFP-SC-grafted $(\boldsymbol{B}, \boldsymbol{F}, \boldsymbol{J})$, BDNF-SC-grafted $(\boldsymbol{C}, \boldsymbol{G}, \boldsymbol{K})$, and NT-3-SC-grafted $(\boldsymbol{D}, \boldsymbol{H}, \boldsymbol{L})$ lesions $21 \mathrm{~d}$ p.i. $\boldsymbol{E}-\boldsymbol{L}$ are enlargements of the boxed areas in $\boldsymbol{A}-\boldsymbol{D}$. The lesion area is delineated by the dashed lines. Staining for PLP and P0 did not overlap. $\boldsymbol{M}-\boldsymbol{P}$, Double immunolabeling for P0 and GFP in an ungrafted lesion $(\boldsymbol{M})$ and in GFP-SC-grafted $(\boldsymbol{N}), \mathrm{BDNF}-\mathrm{SC}$-grafted $(\boldsymbol{0})$, and NT-3-SC-grafted $(\boldsymbol{P})$ lesions showing colocalization of PO and GFP in myelin-like segments. Quantification of remyelination by Schwann cells and oligodendrocytes at $15(\boldsymbol{Q})$ and $21(\boldsymbol{R}) \mathrm{d}$. .i. BDNF and NT-3 improved CNS and PNS remyelination $(n=10)$. Scale bars: (in $\boldsymbol{A}) \boldsymbol{A}-\boldsymbol{D}, 50 \mu \mathrm{m}$; (in $\boldsymbol{E}, \boldsymbol{I}) \boldsymbol{E}-\boldsymbol{L}, 25 \mu \mathrm{m}$; (in $\boldsymbol{M}) \boldsymbol{M}-\boldsymbol{P}, 10 \mu \mathrm{m}$. ${ }^{*} p<0.01$ compared with control.

BDNF- and NT-3-transduced SCs promoted fourfold and sixfold increases in cell proliferation, respectively, compared with control, with a total of $40 \pm 2.1 \mathrm{BrdU}{ }^{+}$cells $/ \mathrm{mm}^{2}$ in ungrafted lesions, $60 \pm$ $1.8 \mathrm{BrdU}^{+}$cells $/ \mathrm{mm}^{2}$ in GFP-SC-grafted lesions, $172 \pm 1.9 \mathrm{BrdU}^{+}$ cells $/ \mathrm{mm}^{2}$ in BDNF-SC-grafted lesions, and $228 \pm 2.3 \mathrm{BrdU}^{+}$cells/ $\mathrm{mm}^{2}$ in NT-3-SC-grafted lesions (Fig. $5 A$ ). However, by $15 \mathrm{~d}$ p.i., the proliferation decreased in all series with $1 \pm 0.5$ cells $/ \mathrm{mm}^{2}$ in ungrafted lesions, $2 \pm 0.7$ cells $/ \mathrm{mm}^{2}$ in the GFP-SC-grafted lesions, $29.2 \pm 1.1$ cells $/ \mathrm{mm}^{2}$ in BDNF-SC-grafted lesions, and $39.2 \pm 0.8$ cells $/ \mathrm{mm}^{2}$ in NT-3-SC-grafted lesions (data not shown). 

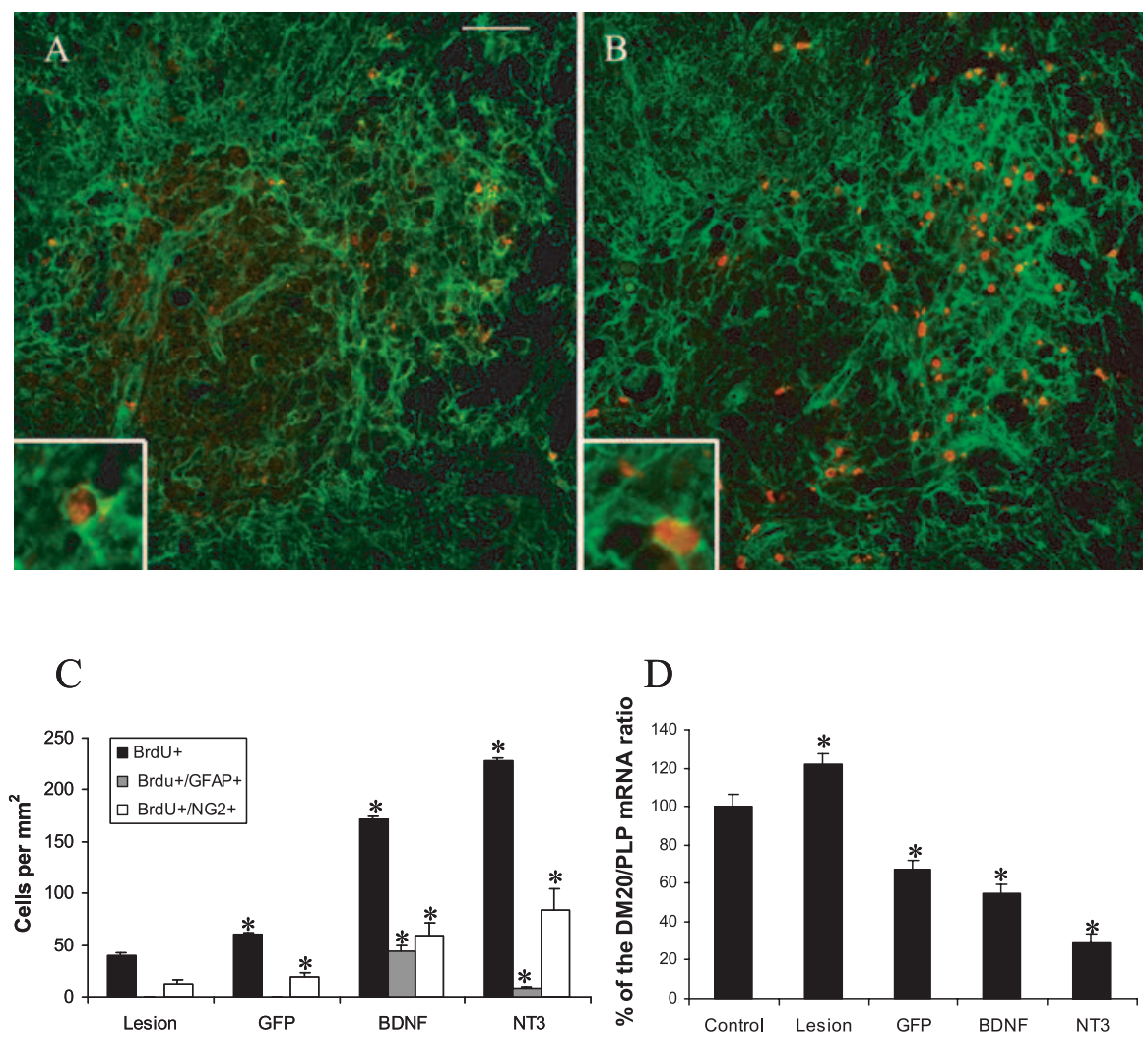

Figure 5. The effect of NT-3 on endogenous glial cell proliferation and differentiation. $A, B$, Double immunolabeling for NG2 (green) and BrdU (red) illustrating NG2 ${ }^{+}$cell proliferation $7 \mathrm{~d}$ p.i. in GFP-SC-grafted $(\boldsymbol{A})$ and NT-3-SC-grafted $(\boldsymbol{B})$ lesions. Insets illustrate $\mathrm{NG2}^{+} / \mathrm{BrdU}^{+}$cells. C, Quantitative evaluation of glial cell proliferation showing that BDNFpromoted proliferation of NG2 ${ }^{+}$and $\mathrm{GFAP}^{+}$cells, whereas NT-3 favored proliferation of NG2 ${ }^{+}$cells (Student's t test; ${ }^{*} p<0.001$ compared with lesioned mice). D, Semiquantitative RT-PCR analysis of PLP/DM20 and PLP mRNA transcripts at $21 \mathrm{~d}$ p.i. DM20/PLP ratios were strongly reduced in BDNF- and NT-3SC-grafted lesions, suggesting OPC differentiation (Student's test; ${ }^{*} p<0.001$ compared with control mice). Scale bar: (in $A$ ) $A, B, 50 \mu \mathrm{m}$.

Double labeling with cell-specific markers showed that BDNF and, to a lesser extent, NT-3 promoted GFAP ${ }^{+}$astrocyte proliferation at $7 \mathrm{~d}$ p.i. (Fig. $5 A-C$ ). Both factors increased NG2 ${ }^{+}$cell proliferation at this time. Proliferation at $15 \mathrm{~d}$ was mainly restricted to $\mathrm{NG}^{+}$cells (data not shown).

\section{BDNF- and NT-3-transduced SCs promote OPC differentiation and central remyelination}

To evaluate the effect of growth factor overexpression on the ability of endogenous OPCs to differentiate into mature oligodendrocytes, we used the previously described ratio of DM20/ PLP as an index of differentiation of the oligodendroglial population present in the lesions $21 \mathrm{~d}$ p.i. (Mathisen et al., 2001). We used semiquantitative RT-PCR to measure the transcript levels of DM20 and PLP in the spinal cords at $21 \mathrm{~d}$ and found a DM20/PLP ratio of 122 in the ungrafted lesions, suggesting the presence of promyelinating oligodendrocytes. In contrast, DM20/PLP ratios in the unlesioned control and GFP-, BDNF-, and NT-3transduced SC-grafted lesions (100, 67, 55, and 29 respectively) showed that all SC grafts, but mainly NT-3-transduced SCs, promoted OPC differentiation (Fig. 5D). This result was confirmed by immunostaining of the axons for 2F11 (data not shown) and of myelin, for which PLP is a major protein of central myelin (Anderson et al., 1997) (Fig. 4A-H). PLP staining did not overlap with P0 staining. Ungrafted lesions contained $17 \pm 2$ $\mathrm{PLP}^{+}$thin myelin-like profiles at $15 \mathrm{~d}$ and $30 \pm 4$ at $21 \mathrm{~d}$. The number of $\mathrm{PLP}^{+}$myelin-like profiles per lesion increased by 9.8-, 13.2-, and 22.3-fold in GFP-, BDNF-, and NT-3-SC- grafted lesions, respectively, at $15 \mathrm{~d}$ (Fig. $4 Q)$ and 7.5-, 12-, and 15-fold at $21 \mathrm{~d}$ (Fig. $4 R$ ), thus indicating that $\mathrm{BDNF}$ and NT-3 accelerated endogenous remyelination compared with untransplanted or SC-transplanted lesions. When related with the amount of $\mathrm{P}^{+}$ profiles, the data showed that BDNF and NT-3 promoted first CNS remyelination and then PNS remyelination.

\section{NT-3 overexpression \\ modulates astrogliosis}

Grafted SCs are known to elicit a strong astrogliosis-limiting remyelination and axonal regrowth (Blakemore and Patterson, 1975; Shields et al., 2000; Blakemore et al., 2003). To investigate whether BDNF or NT-3 modified astrocyte reactivity, sections of each series were double stained for GFAP and the chondroitin sulfate proteoglycan, Cs56, an inhibitory extracellular matrix protein, or for laminin to stain basal lamina. Seven days postinjection, lesions without grafts or those containing GFP- or BDNF-SC grafts were surrounded by a tight layer of highly branched $\mathrm{GFAP}^{+}$cells (Fig. 6A-C) and characterized by a strong expression of Cs56 (data not shown). However, lesions grafted with NT-3-SCs were surrounded by fewer $\mathrm{GFAP}^{+}$astrocytes (Fig. 6D). Moreover, Cs56 expression was reduced and did not merge with GFAP expression (data not shown). In addition, laminin was strongly expressed in basal lamina-like structures around blood vessels in ungrafted lesions and around blood vessels and SCs in the lesions grafted with GFP-SCs and BDNF-SCs (Fig. $6 B, C)$. However, only punctate laminin ${ }^{+}$deposits were found in lesions grafted with NT-3-SCs (Fig. 6D), suggesting that NT-3 decreases astrogliosis.

\section{Transduced SCs enhance neuroprotection and regeneration}

Because LPC injection is likely to produce axonal injury, we analyzed the status of axonal preservation using Bodian staining or immunostaining for 2F11. To determine whether BDNF and NT-3 overexpression favored axonal preservation in the demyelinated areas, we quantified the number of axonal structures per surface in the lesion. Data showed that GFP-, NT-3-, and BDNFSCs improved axon sparing at $7 \mathrm{~d}$ p.i. (data not shown) and $21 \mathrm{~d}$ p.i. (Fig. $7 A-H$ ). Quantification at $21 \mathrm{~d}$ p.i. indicated that the number of linear axonal structures was increased 1.7-fold in GFP-, 2.5-fold in BDNF-, and 2.7-fold in NT-3-SC-grafted lesions compared with ungrafted lesions (Fig. 7I). We also used GAP-43, a sensitive marker of the regenerative response to axonal damage, to confirm the effects of BDNF and NT-3 on axonal regeneration. The number of GAP $-43^{+}$nerve endings was twofold higher in the BDNF-SC-grafted $\left(32 \pm 4.16\right.$ per $\left.\mathrm{mm}^{2}\right)$ and NT-3-SC-grafted $\left(32 \pm 3.78\right.$ per $\left.\mathrm{mm}^{2}\right)$ lesions and significantly differed from the number of GAP- $43^{+}$nerve endings found in GFP-SC-grafted $\left(16.24 \pm 2.16\right.$ per $\left.\mathrm{mm}^{2}\right)$ and ungrafted $(14.24 \pm$ 1.68 per $\mathrm{mm}^{2}$ ) lesions (Fig. $7 J$ ). 


\section{Discussion}

In the present study, we analyzed the effects of BDNF- and NT-3-transduced SCs on the repair of the demyelinated spinal cord. We demonstrate that using a lentivirus-derived vector to transfer the neurotrophin genes, transduced primate SCs successfully overexpressed BDNF and NT-3. Moreover, when grafted in the demyelinated spinal cord, transduced SCs promoted clinical recovery, which correlated with enhanced OPC proliferation, OPC and SC differentiation, axonal protection, and reduced astrogliosis. These results provide evidence that transplantation of genetically modified SCs to overexpress neurotrophins may be of therapeutic value to promote CNS myelin repair.

Various types of genetically transduced cells were used as implants to deliver neurotrophic factors in damaged areas of the CNS (Tuszynski et al., 1994; Schinstine et al., 1995; Yoshimoto et al., 1995; Eaton and Whittemore, 1996; Nakahara et al., 1996). Among them, SCs were used as cellular vectors for axonal regeneration in contused or hemisected spinal cord (Menei et al., 1998; Tuszynski et al., 1998). However, despite their poor sensitivity to most demyelinating diseases of the CNS and their potential for myelin repair, their use for transfer of genes acting as paracrine/autocrine activators of CNS remyelination was never described. We demonstrate here that SCs can be successfully used to deliver neurotrophic factors in LPC-induced demyelination. Under normal conditions, BDNF mRNA is barely detectable in peripheral nerve but is increased after nerve lesion (Acheson et al., 1991; Funakoshi et al., 1993) or isolation in culture (Meyer et al., 1992). Using lentiviral vectors, which integrate in the genome of dividing and nondividing cells with high efficiency, we show that overexpressing BDNF and NT-3 in primary cultures of macaque SCs increased tremendously the amount of BDNF and NT-3 secreted by these cells (35- and 62.5-fold, respectively). In addition, the secreted human BDNF and NT-3 were biologically active, because they promoted SC differentiation in vitro and in vivo leading to increased functional recovery and morphological repair.

We also provide evidence that high concentrations of BDNF released by transduced SCs inhibited their proliferation and favored their differentiation. A similar effect was observed on native macaque SCs exposed to BDNF-SC conditioned medium (data not shown). These observations are consistent with the demonstration that binding of BDNF to p75 $100 \mu \mathrm{m}$; (in $\boldsymbol{E}) \boldsymbol{E}-\boldsymbol{H}, 50 \mu \mathrm{m}$.
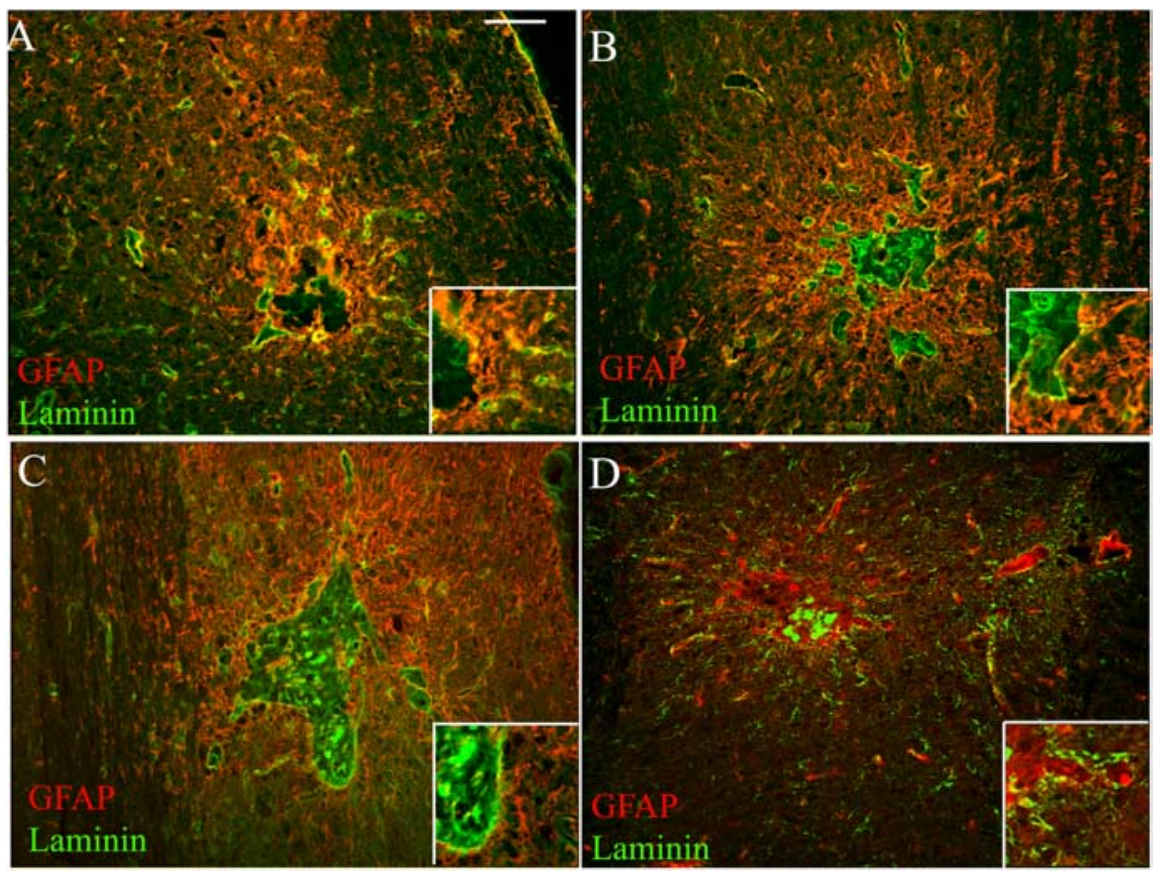

Figure 6. Effect of BDNF and NT-3 on astrogliosis $7 \mathrm{~d}$ p.i. Double immunodetection of GFAP (red) and laminin (green) in ungrafted $(\boldsymbol{A})$ and in GFP-SC-grafted $(\boldsymbol{B})$, BDNF-SC-grafted (C), and NT-3-SC-grafted $(\boldsymbol{D})$ lesions revealed a decrease of GFAP and the absence of basal lamina-like structures in response to NT-3. Scale bar: (in $\boldsymbol{A}) \boldsymbol{A}-\boldsymbol{D}, 100 \mu \mathrm{m}$.

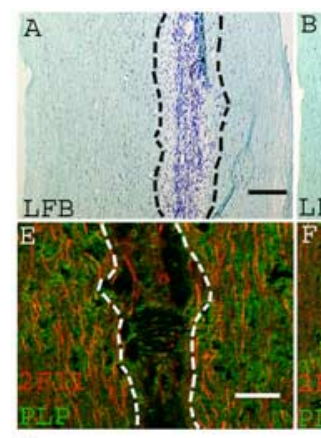

I

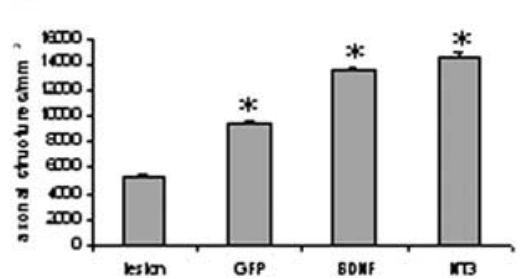

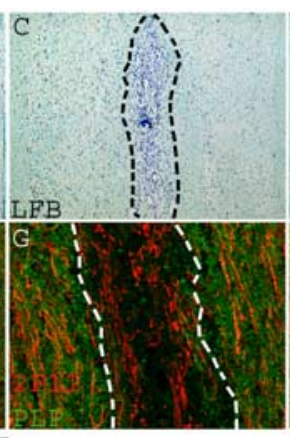

丁

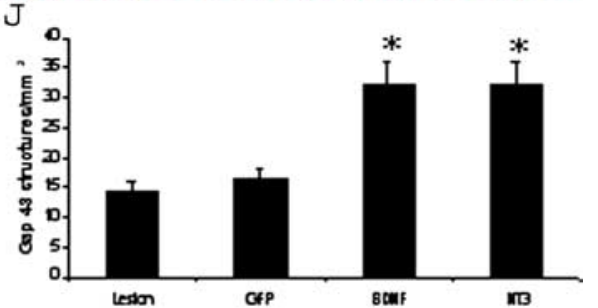

Figure 7. Effect of BDNF and NT-3 on axonal preservation. A-D, Luxol fast blue staining illustrates the general view of the lesions at $21 \mathrm{~d}$ p.i. $\boldsymbol{E}-\boldsymbol{H}$, Enlargement of each lesion showing double immunolabeling for $2 \mathrm{~F} 11$ (red) and PLP (green): $\boldsymbol{A}, \boldsymbol{E}$, ungrafted lesion; $\boldsymbol{B}, \boldsymbol{F}, \mathrm{GFP}-\mathrm{SC}$; $\boldsymbol{C}, \boldsymbol{G}, \mathrm{BDNF}-\mathrm{SC} ; \boldsymbol{D}, \boldsymbol{H}$, NT-3-SC-grafted lesions. The number of linear axonal profiles increased progressively from $\boldsymbol{E}$ to $\boldsymbol{H}$. I-J, Quantification of linear axonal profiles in lesions $21 \mathrm{~d}$ p.i. $(\boldsymbol{I})$ and GAP-43 structures in lesions $7 \mathrm{~d}$ p.i $(\boldsymbol{J})$. The number of linear axonal profiles and the number of GAP- $43^{+}$structures in the demyelinated lesion grafted with BDNF and NT-3-SCs were higher than in ungrafted lesions (Student's $t$ test; ${ }^{*} p<0.001$ compared with lesioned mice). Scale bars: (in $\boldsymbol{A}$ ) $\boldsymbol{A}-\boldsymbol{D}$,

neurotrophin receptor activates myelin gene expression by SCs in vitro and in vivo in the presence of axons (Cosgaya et al., 2002). A similar effect was observed with NT-3, which is in contrast to previous reports in vitro. This discrepancy may be accounted for variance in culture conditions between the two studies. In particular, we used high concentrations of forskolin and insulin, which 
elevate cAMP, inhibit DNA synthesis, and induce P0 expression in quiescent SCs in vitro (Morgan et al., 1991). Another possible explanation is that, because of its constitutive overexpression in transduced SCs and high levels of secretion, NT-3 did not totally associate with its TrkC scavenger receptor and excess NT-3 interacted with p75 neurotrophin receptor competitively with BDNF (Rodriguez-Tebar et al., 1992). These interactions could inhibit primate SC proliferation and allow their differentiation in the absence of other competing neurotrophins such as NGF commonly used in DRG coculture systems (Cosgaya et al., 2002).

We found a twofold increase in the average number of antihuman nuclei ${ }^{+} / \mathrm{GFP}^{+}$cells in NT-3-SC-grafted spinal cords compared with control and BDNF-SC-grafted spinal cords but found no evidence of proliferation in the SC population. The absence of proliferation in the grafted and host SC populations in the BDNF and NT-3 series confirms the hypothesis that NT-3 is a SC prosurvival factor in vivo as well as in vitro (Meier et al., 1999). Moreover, the fourfold increase in the number of $\mathrm{GFP}^{+} / \mathrm{P} 0^{+}$ structures in the NT-3-SC series, compared with controls and BDNF-SC grafts, reinforces our in vitro observations that NT-3 overexpression promotes transplanted SC differentiation. Our data also show a dramatic increase in $\mathrm{P}^{+} / \mathrm{GFP}^{-}$myelin-like profiles in the lesions, suggesting increased remyelination by endogenous SCs. In vitro, NT-3 promotes SC migration, whereas BDNF inhibits this process under the same conditions (Yamauchi et al., 2004 ), suggesting that the increased number of $\mathrm{PO}^{+} / \mathrm{GFP}^{-}$myelinlike profiles in the lesions could result from enhanced recruitment and differentiation of the endogenous SC populations.

There is a great deal of evidences that OPCs residing in the mature CNS are the major source of remyelinating oligodendrocytes (Franklin, 2002). In the spinal cord, these adult OPCs proliferate in response to demyelination (Carroll and Jennings, 1994; Keirstead et al., 1998; Redwine and Armstrong, 1998; Reynolds et al., 2001), and it is well documented that an array of growth factors, including BDNF and NT-3, increases their proliferation and survival in vitro (McMorris and McKinnon, 1996; Rubio et al., 2004). Previous studies based on ex vivo gene transfer (McTigue et al., 1998) or direct injection of NT-3 (Jean et al., 2003) showed that NT-3 promotes a fivefold increase in the number of proliferating OPCs after injury. We obtained similar results after transplantation of BDNF-transduced (4.6-fold) and NT-3transduced (6.5-fold) SCs in demyelinated spinal cords. Interestingly, OPC proliferation was maximal before the end of the first week postinjection and decreased thereafter, indicating that growth factor-induced proliferation of OPCs was transient and that lesion-induced signals of differentiation may overrule growth factor-induced signals of proliferation. Consistent with these observations, BDNF, but mainly NT-3, overexpression increased the DM20/PLP ratio, suggesting OPC differentiation into oligodendrocytes. It could be argued that the PLP/DM20 ratio may also reflect SC contribution to remyelination, because PLP/ DM20 proteins are expressed in the PNS (Pham-Dinh et al., 1991). However, PLP and DM20 are expressed in low amounts and are not incorporated in PNS myelin (Anderson et al., 1997). Moreover, DM20 levels are higher than PLP and remain unchanged by axonal contacts in the PNS (Jiang et al., 2000), suggesting that SC remyelination may have little influence on the PLP/DM20 ratios in CNS remyelination. Immunostaining for PLP confirms that neurotrophins accelerate CNS remyelination 2 weeks after transplantation, thus indicating that neurotrophininduced OPC proliferation at $7 \mathrm{~d}$ results in enhanced CNS remyelination at later times.

Damage to the CNS results in glial scar formation associated with recruitment of microglia, meningeal cells, and astrocytes (Blakemore et al., 1977; Abnet et al., 1991; Dusart et al., 1991; Kreutzberg, 1996). Most of these cells produce nonpermissive molecules, including extracellular matrix molecules such as the chondroitin sulfate proteoglycans (CSPGs) (Fitch and Silver, 1997), which may inhibit axonal regeneration and OPC recruitment in chronic multiple sclerosis (MS) lesions. When SCs are grafted in the CNS, they elicit a strong interface with astrocytes (Wilby et al., 1999). SC-astrocyte interaction is correlated with upregulation of CSPGs in vitro and in vivo (Ghirnikar and Eng, 1995; Lakatos et al., 2000; Plant et al., 2001), and chondroitinase digestion of CSPG reduces this SC-astrocyte interface in vitro (Grimpe and Silver, 2004). We show that transplantation of NT3-transduced SCs induced similar changes in vivo. The density of astrocytes was strongly reduced compared with other conditions. Decreased astrogliosis correlated with low levels of Cs56 immunoreactivity. Moreover, laminin was not concentrated in linear basal lamina-like structures around the graft but formed punctate deposits throughout the lesion. Although basal lamina may prevent OPC recruitment and axon regeneration, substratebound laminin may favor these events (Baron-Van Evercooren et al., 1982; Manthorpe et al., 1983; Kiernan et al., 1996; Schmidt et al., 1997). It has been hypothesized that regeneration is successful when local permissive signals balance and exceed inhibitory signals (Jones et al., 2003). Our observations suggest that NT-3 overexpression tips the permissive-inhibitory balance in favor of axonal growth and OPC recruitment in the lesion site by reducing inhibitory components such as Cs56 and basal lamina formation and by promoting permissive components such as substratebound laminin.

Myelin components such as Nogo, Mag, and Omgp prevent axonal regeneration in the CNS. It has been demonstrated that treatments with BDNF, NT-3, dibutyril cAMP, or their combination overcome myelin inhibition (Lu et al., 2004; Pearse et al., 2004). The two neurotrophins could have a direct effect on regenerating axons, the cell bodies of which express the highaffinity receptors for BDNF (TrkB) and NT-3 (TrkC), allowing axons to respond to these factors after injury (Schnell et al., 1994; Kim et al., 1996; Grill et al., 1997; Houweling et al., 1998). Based on the results of two different behavioral analyses, our study shows that native primate SC engraftment leads to effective, but partial, functional recovery after $22 \mathrm{~d}$. In contrast, BDNF-SCand NT-3-SC-grafted animals recovered from day 7 after transplantation and, from this stage on, their score did not significantly differ from the unlesioned animal score. Such an early recovery is most likely attributable to improved neuroprotection rather than remyelination, which occurred at 2 and 3 weeks (Fig. $4 Q, R)$ after transplantation.

Remyelination strategies based on cell or gene transfer or their combination for MS may address the issue of first avoiding the establishment of permanent disabilities and, second, allowing recovery of altered functions. Both issues require a combination of axonal preservation and efficient remyelination. Allowing robust preservation of the axonal target during the early stages of the process is a key issue for successful remyelination. This is clearly the case in our study in which the morphological findings are consistent with the locomotor performances of treated animals. Rapid functional recovery and its maintenance reflect the decrease in axonal suffering and axonal loss associated with signs of axonal regeneration during the earliest stage in the NT-3 and BDNF series. These initial effects, followed by improved remyelination at a later stage, underline the interest of combining neu- 
roprotection with activation of myelin-forming cells in search of the cure of demyelinating diseases of the CNS.

\section{References}

Abnet K, Fawcett JW, Dunnett SB (1991) Interactions between meningeal cells and astrocytes in vivo and in vitro. Brain Res Dev Brain Res 59:187-196.

Acheson A, Barker PA, Alderson RF, Miller FD, Murphy RA (1991) Detection of brain-derived neurotrophic factor-like activity in fibroblasts and Schwann cells: inhibition by antibodies to NGF. Neuron 7:265-275.

Anderson TJ, Montague P, Nadon N, Nave KA, Griffiths IR (1997) Modification of Schwann cell phenotype with Plp transgenes: evidence that the PLP and DM20 isoproteins are targeted to different cellular domains. J Neurosci Res 50:13-22.

Avellana-Adalid V, Bachelin C, Lachapelle F, Escriou C, Ratzkin B, BaronVan Evercooren A (1998) In vitro and in vivo behaviour of NDFexpanded monkey Schwann cells. Eur J Neurosci 10:291-300.

Bachelin C, Lachapelle F, Girard C, Moissonnier P, Serguera-Lagache C, Mallet J, Fontaine D, Chojnowski A, Le Guern E, Nait-Oumesmar B, BaronVan Evercooren A (2005) Efficient myelin repair in the macaque spinal cord by autologous grafts of Schwann cells. Brain 128:540-549.

Baron-Van Evercooren A, Blakemore W (2004) Remyelination through engraftment. In: Myelin biology and disorders, Chap 6 (Lazzarini R, Griffin J, Lassmann H, Nave K-A, Miller R, Trapp B, eds), pp 143-172. San Diego: Elsevier.

Baron-Van Evercooren A, Kleinman HK, Ohno S, Marangos P, Schwartz JP, Dubois-Dalcq ME (1982) Nerve growth factor, laminin, and fibronectin promote neurite growth in human fetal sensory ganglia cultures. J Neurosci Res 8:179-193.

Baron-Van Evercooren A, Gansmuller A, Duhamel E, Pascal F, Gumpel M (1992) Repair of a myelin lesion by Schwann cells transplanted in the adult mouse spinal cord. J Neuroimmunol 40:235-242.

Barres BA, Schmid R, Sendnter M, Raff MC (1993) Multiple extracellular signals are required for long-term oligodendrocyte survival. Development 118:283-295.

Barres BA, Raff MC, Gaese F, Bartke I, Dechant G, Barde YA (1994) A crucial role for neurotrophin-3 in oligodendrocyte development. Nature 367:371-375.

Blakemore WF, Crang AJ (1985) The use of cultured autologous Schwann cells to remyelinate areas of persistent demyelination in the central nervous system. J Neurol Sci 70:207-223.

Blakemore WF, Patterson RC (1975) Observations on the interactions of Schwann cells and astrocytes following X-irradiation of neonatal rat spinal cord. J Neurocytol 4:573-585.

Blakemore WF, Eames RA, Smith KJ, McDonald WI (1977) Remyelination in the spinal cord of the cat following intraspinal injections of lysolecithin. J Neurol Sci 33:31-43.

Blakemore WF, Gilson JM, Crang AJ (2003) The presence of astrocytes in areas of demyelination influences remyelination following transplantation of oligodendrocyte progenitors. Exp Neurol 184:955-963.

Bottenstein JE, Sato GH (1979) Growth of a rat neuroblastoma cell line i serum-free supplemented medium. Proc Natl Acad Sci USA:514-517.

Cao L, Liu L, Chen ZY, Wang LM, Ye JL, Qiu HY, Lu CL, He C (2004) Olfactory ensheathing cells genetically modified to secrete GDNF to promote spinal cord repair. Brain 127:535-549.

Carroll WM, Jennings AR (1994) Early recruitment of oligodendrocyte precursors in CNS demyelination. Brain 117:563-578.

Chan J, Cosgaya J, Wu Y, Shooter E (2001) Neurotrophins are key mediators of the myelination program in the peripheral nervous system. Proc Natl Acad Sci USA 98:14661-14668.

Charneau P, Alizon M, Clavel F (1992) A second origin of DNA plus-strand synthesis is required for optimal human immunodeficiency virus replication. J Virol 66:2814-2820.

Cosgaya JM, Chan JR, Shooter EM (2002) The neurotrophin receptor p75NTR as a positive modulator of myelination. Science 298:1245-1248.

Duncan ID, Aguayo AJ, Bunge RP, Wood PM (1981) Transplantation of rat Schwann cells grown in tissue culture into the mouse spinal cord. J Neurol Sci 49:241-252.

Dunham NW, Miya TS (1957) A note on a simple apparatus for detecting neurological deficit in rats and mice. J Am Pharm Assoc 46:208-209.

Dusart I, Marty S, Peschanski M (1991) Glial changes following an excitotoxic lesion in the CNS-II. Astrocytes. Neuroscience 45:541-549.
Eaton MJ, Whittemore SR (1996) Autocrine BDNF secretion enhances the survival and serotonergic differentiation of raphe neuronal precursor cells grafted into the adult rat CNS. Exp Neurol 140:105-114.

Fitch MT, Silver J (1997) Activated macrophages and the blood-brain barrier: inflammation after CNS injury leads to increases in putative inhibitory molecules. Exp Neurol 148:587-603.

Franklin RJ (2002) Why does remyelination fail in multiple sclerosis? Nat Rev Neurosci 3:705-714.

Funakoshi H, Frisen J, Barbany G, Timmusk T, Zachrisson O, Verge VM, Persson H (1993) Differential expression of mRNAs for neurotrophins and their receptors after axotomy of the sciatic nerve. J Cell Biol 123:455-465.

Ghirnikar RS, Eng LF (1995) Chondroitin sulfate proteoglycan staining in astrocyte-Schwann cell co-cultures. Glia 14:145-152.

Grill R, Murai K, Blesch A, Gage FH, Tuszynski MH (1997) Cellular delivery of neurotrophin-3 promotes corticospinal axonal growth and partial functional recovery after spinal cord injury. J Neurosci 17:5560-5572.

Grimpe B, Silver J (2004) A novel DNA enzyme reduces glycosaminoglycan chains in the glial scar and allows microtransplanted dorsal root ganglia axons to regenerate beyond lesions in the spinal cord. J Neurosci 24:1393-1397.

Honmou O, Felts PA, Waxman SG, Kocsis JD (1996) Restoration of normal conduction properties in demyelinated spinal cord axons in the adult rat by transplantation of exogenous Schwann cells. J Neurosci 16:3199-3208.

Houweling DA, Lankhorst AJ, Gispen WH, Bar PR, Joosten EA (1998) Collagen containing neurotrophin-3 (NT-3) attracts regrowing injured corticospinal axons in the adult rat spinal cord and promotes partial functional recovery. Exp Neurol 153:49-59.

Jean I, Lavialle C, Barthelaix-Pouplard A, Fressinaud C (2003) Neurotrophin-3 specifically increases mature oligodendrocyte population and enhances remyelination after chemical demyelination of adult rat CNS. Brain Res 972:110-118.

Jiang H, Duchala CS, Awatramani R, Shumas S, Carlock L, Kamholz J, Garbern J, Scherer SS, Shy ME, Macklin WB (2000) Proteolipid protein mRNA stability is regulated by axonal contact in the rodent peripheral nervous system. J Neurobiol 44:7-19.

Jones LL, Sajed D, Tuszynski MH (2003) Axonal regeneration through regions of chondroitin sulfate proteoglycan deposition after spinal cord injury: a balance of permissiveness and inhibition. J Neurosci 23:9276-9288.

Keirstead HS, Levine JM, Blakemore WF (1998) Response of the oligodendrocyte progenitor cell population (defined by NG2 labelling) to demyelination of the adult spinal cord. Glia 22:161-170.

Kerschensteiner M, Stadelmann C, Buddeberg BS, Merkler D, Bareyre FM, Anthony DC, Linington C, Bruck W, Schwab ME (2004) Targeting experimental autoimmune encephalomyelitis lesions to a predetermined axonal tract system allows for refined behavioral testing in an animal model of multiple sclerosis. Am J Pathol 164:1455-1469.

Kiernan BW, Gotz B, Faissner A, ffrench-Constant C (1996) Tenascin-C inhibits oligodendrocyte precursor cell migration by both adhesiondependent and adhesion-independent mechanisms. Mol Cell Neurosci 7:322-335.

Kim DH, Gutin PH, Noble LJ, Nathan D, Yu JS, Nockels RP (1996) Treatment with genetically engineered fibroblasts producing NGF or BDNF can accelerate recovery from traumatic spinal cord injury in the adult rat. NeuroReport 7:2221-2225.

Klinguer C, Trifilieff E (1994) Characterization and comparison of the polyclonal immune response to purified PLP and DM-20 in the Lewis rat: determination of a new antigenic determinant. Neurochem Int 25:433-440.

Kreutzberg GW (1996) Microglia: a sensor for pathological events in the CNS. Trends Neurosci 19:312-318.

Lakatos A, Franklin RJ, Barnett SC (2000) Olfactory ensheathing cells and Schwann cells differ in their in vitro interactions with astrocytes. Glia 32:214-225.

Lu P, Yang H, Jones LL, Filbin MT, Tuszynski MH (2004) Combinatorial therapy with neurotrophins and cAMP promotes axonal regeneration beyond sites of spinal cord injury. J Neurosci 24:6402-6409.

Manthorpe M, Engvall E, Ruoslahti E, Longo FM, Davis GE, Varon S (1983) Laminin promotes neuritic regeneration from cultured peripheral and central neurons. J Cell Biol 97:1882-1890.

Mathisen PM, Kawczak JA, Yu M, Johnson JM, Tuohy VK (2001) Differen- 
tial DM20 mRNA expression distinguishes two distinct patterns of spontaneous recovery from murine autoimmune encephalomyelitis. J Neurosci Res 64:542-551.

McGavern DB, Murray PD, Rodriguez M (1999) Quantitation of spinal cord demyelination, remyelination, atrophy, and axonal loss in a model of progressive neurologic injury. J Neurosci Res 58:492-504.

McMorris FA, McKinnon RD (1996) Regulation of oligodendrocyte development and CNS myelination by growth factors: prospects for therapy of demyelinating disease. Brain Pathol 6:313-329.

McTigue DM, Horner PJ, Stokes BT, Gage FH (1998) Neurotrophin-3 and brain-derived neurotrophic factor induce oligodendrocyte proliferation and myelination of regenerating axons in the contused adult rat spinal cord. J Neurosci 18:5354-5365.

Meier C, Parmantier E, Brennan A, Mirsky R, Jessen KR (1999) Developing Schwann cells acquire the ability to survive without axons by establishing an autocrine circuit involving insulin-like growth factor, neurotrophin-3, and platelet-derived growth factor-BB. J Neurosci 19:3847-3859.

Menei P, Montero-Menei C, Whittemore SR, Bunge RP, Bunge MB (1998) Schwann cells genetically modified to secrete human BDNF promote enhanced axonal regrowth across transected adult rat spinal cord. Eur J Neurosci 10:607-621.

Meyer M, Matsuoka I, Wetmore C, Olson L, Thoenen H (1992) Enhanced synthesis of brain-derived neurotrophic factor in the lesioned peripheral nerve: different mechanisms are responsible for the regulation of BDNF and NGF mRNA. J Cell Biol 119:45-54.

Morgan L, Jessen K, Mirsky R (1991) The effects of cAMP on differentiation of cultured Schwann cells: progression from an early phenotype (04+) to a myelin phenotype (P0+, GFAP-, N-CAM-, NGF-receptor-) depends on growth inhibition. J Cell Biol 112:457-467.

Morrissey TK, Kleitman N, Bunge RP (1995) Human Schwann cells in vitro. II. Myelination of sensory axons following extensive purification and heregulin-induced expansion. J Neurobiol 28:190-201.

Murray PD, McGavern DB, Sathornsumetee S, Rodriguez M (2001) Spontaneous remyelination following extensive demyelination is associated with improved neurological function in a viral model of multiple sclerosis. Brain 124:1403-1416.

Nakahara Y, Gage FH, Tuszynski MH (1996) Grafts of fibroblasts genetically modified to secrete NGF, BDNF, NT-3, or basic FGF elicit differential responses in the adult spinal cord. Cell Transplant 5:191-204.

Nishiyama A, Lin XH, Giese N, Heldin CH, Stallcup WB (1996) Colocalization of NG2 proteoglycan and PDGF alpha-receptor on O2A progenitor cells in the developing rat brain. J Neurosci Res 43:299-314.

Oudega M, Gautier SE, Chapon P, Fragoso M, Bates ML, Parel JM, Bunge MB (2001) Axonal regeneration into Schwann cell grafts within resorbable poly(alpha-hydroxyacid) guidance channels in the adult rat spinal cord. Biomaterials 22:1125-1136.

Pearse DD, Pereira FC, Marcillo AE, Bates ML, Berrocal YA, Filbin MT, Bunge MB (2004) cAMP and Schwann cells promote axonal growth and functional recovery after spinal cord injury. Nat Med 10:610-616.

Pham-Dinh D, Birling MC, Roussel G, Dautigny A, Nussbaum JL (1991) Proteolipid DM-20 predominates over PLP in peripheral nervous system. NeuroReport 2:89-92.

Plant GW, Bates ML, Bunge MB (2001) Inhibitory proteoglycan immunoreactivity is higher at the caudal than the rostral Schwann cell grafttransected spinal cord interface. Mol Cell Neurosci 17:471-487.

Ranscht B, Clapshaw PA, Price J, Noble M, Seifert W (1982) Development of oligodendrocytes and Schwann cells studied with a monoclonal antibody against galactocerebroside. Proc Natl Acad Sci USA 79:2709-2713.

Redwine JM, Armstrong RC (1998) In vivo proliferation of oligodendrocyte progenitors expressing PDGFalphaR during early remyelination. J Neurobiol 37:413-428.

Reynolds R, Cenci di Bello I, Dawson M, Levine J (2001) The response of adult oligodendrocyte progenitors to demyelination in EAE. Prog Brain Res 132:165-174.

Rodriguez-Tebar A, Dechant G, Gotz R, Barde Y (1992) Binding of neurotrophin-3 to its neuronal receptors and interactions with nerve growth factor and brain-derived neurotrophic factor. EMBO J 11:917-922.

Rubio N, Rodriguez R, Arevalo MA (2004) In vitro myelination by oligodendrocyte precursor cells transfected with the neurotrophin-3 gene. Glia 47:78-87.

Schinstine M, Fiore DM, Winn SR, Emerich DF (1995) Polymerencapsulated Schwannoma cells expressing human nerve growth factor promote the survival of cholinergic neurons after a fimbria-fornix transection. Cell Transplant 4:93-102.

Schmidt C, Ohlemeyer C, Labrakakis C, Walter T, Kettenmann H, Schnitzer J (1997) Analysis of motile oligodendrocyte precursor cells in vitro and in brain slices. Glia 20:284-298.

Schnell L, Schneider R, Kolbeck R, Barde YA, Schwab ME (1994) Neurotrophin-3 enhances sprouting of corticospinal tract during development and after adult spinal cord lesion. Nature 367:170-173.

Shields SA, Blakemore WF, Franklin RJ (2000) Schwann cell remyelination is restricted to astrocyte-deficient areas after transplantation into demyelinated adult rat brain. J Neurosci Res 60:571-578.

Tolwani R, Cosgaya J, Varma S, Jacob R, Kuo L, Shooter E (2004) BDNF overexpression produces a long-term increase in myelin formation in the peripheral nervous system. J Neurosci Res 77:662-669.

Tuszynski MH, Peterson DA, Ray J, Baird A, Nakahara Y, Gage FH (1994) Fibroblasts genetically modified to produce nerve growth factor induce robust neuritic ingrowth after grafting to the spinal cord. Exp Neurol 126:1-14.

Tuszynski MH, Weidner N, McCormack M, Miller I, Powell H, Conner J (1998) Grafts of genetically modified Schwann cells to the spinal cord: survival, axon growth, and myelination. Cell Transplant 7:187-196.

Wilby MJ, Muir EM, Fok-Seang J, Gour BJ, Blaschuk OW, Fawcett JW (1999) N-Cadherin inhibits Schwann cell migration on astrocytes. Mol Cell Neurosci 14:66-84.

Xu X, Zhang S, Li H, Aebischer P, Bunge M (1999) Regrowth of axons into the distal spinal cord through a Schwann-cell-seeded mini-channel implanted into hemisected adult rat spinal cord. Eur J Neurosci 11:1723-1740.

Yamauchi J, Chan J, Shooter E (2004) Neurotrophins regulate Schwann cell migration by activating divergent signaling pathways dependent on Rho GTPases. Proc Natl Acad Sci USA 101:8774-8779.

Yan H, Wood PM (2000) NT-3 weakly stimulates proliferation of adult rat $\mathrm{O} 1(-) \mathrm{O} 4(+)$ oligodendrocyte-lineage cells and increases oligodendrocyte myelination in vitro. J Neurosci Res 62:329-335.

Yoshimoto Y, Lin Q, Collier TJ, Frim DM, Breakefield XO, Bohn MC (1995) Astrocytes retrovirally transduced with BDNF elicit behavioral improvement in a rat model of Parkinson's disease. Brain Res 691:25-36.

Yoshimura K, Negishi T, Kaneko A, Sakamoto Y, Kitamura K, Hosokawa T, Hamaguchi K, Nomura M (1996) Monoclonal antibodies specific to the integral membrane protein $\mathrm{P} 0$ of bovine peripheral nerve myelin. Neurosci Res 25:41-49.

Zennou V, Petit C, Guetard D, Nerhbass U, Montagnier L, Charneau P (2000) HIV-1 genome nuclear import is mediated by a central DNA flap. Cell 101:173-185.

Zennou V, Serguera C, Sarkis C, Colin P, Perret E, Mallet J, Charneau P (2001) The HIV-1 DNA flap stimulates HIV vector-mediated cell transduction in the brain. Nat Biotechnol 19:446-450.

Zhang J, Luo X, Xian C, Liu Z, Zhou X (2000) Endogenous BDNF is required for myelination and regeneration of injured sciatic nerve in rodents. Eur J Neurosci 12:4171-4180. 